\title{
ПАМЯТИ З.Ж. ШАРДЕНОВОЙ
}

\section{(C) 2019 г. А.А. Ержигитова}

В заметке изложены основные вехи научного творчества 3.Ж. Шарденовой, ушедшей из жизни в начале марта 2019 г. Трудовая биография Зухры Жанатаевны в основном связана с деятельностью сначала в отделе археологии Института истории, археологии и этнографии им. Ч.Ч. Валиханова, а затем в отделе урбанизации и номадизма Института археологии им. А.Х. Маргулана. Сфера научных интересов 3.Ж. Шарденовой, архитектора по специальности, предполагала изучение конструктивных особенностей сооружений памятников городской культуры средних веков. Кандидатская диссертация была посвящена анализу жилой архитектуры Южного Казахстана и Жетысу с начала IV по IX вв. В последние годы жизни 3.Ж. Шарденова занималась изучением архитектурных особенностей замка Акыртас.

Ключевые слова: археология, З.Ж. Шарденова, архитектор, архитектура средневековья

Шарденова Зухра Жанатаевна родилась 16 апреля 1956 года в городе Алма-Ата в семье казахстанского художника-живописца, Народного художника Казахской ССР Жанатая Шарденова.

В 1978 г. окончила архитектурный факультет Казахского государственного политехнического института. По распределению института была направлена в Государственный проектный институт «АлмаАтагипрогор», где проработала до 1987 года в должности архитектора, а затем старшего архитектора. В 1987 г. Зухра Жанатаевна была принята в отдел археологии Института истории, археологии и этнографии им. Ч.Ч. Валиханова.

В период с 1989 по 1992 годы 3.Ж. Шарденова обучалась в аспирантуре Академии наук Казахстана.

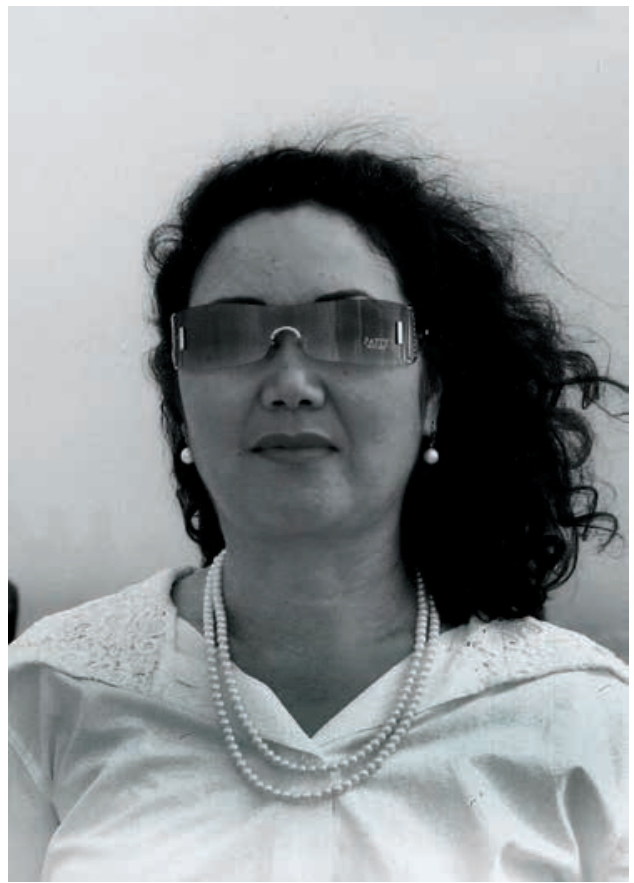

Зухра Жанатаевна Шарденова

Zukhra J. Shardenova 
В это время она принимала активное участие в подготовке Свода памятников истории и культуры Казахстана: участвовала в археологических исследованиях; занималась обмерами памятников; съемкой раскопанных объектов. З.Ж. Шарденовой подготовлена основная часть графического материала по памятникам Чимкентской (ныне Туркестанской) и Джамбульской (Жамбылской) областей.

После успешной защиты кандидатской диссертации на тему «Раннесредневековая жилая архитектура Южного Казахстана и Семиречья с начала IV по IX вв.». в Ташкентском архитектурно-строительном институте в 1995 г. ей была присвоена ученая степень кандидата архитектуры. Работа была подготовлена под руководством академика Академии наук Республики Узбекистан, доктора искусствоведения Пуганчековой Г.А. и члена-корреспондента Национальной академии наук Республики Казахстан, доктора исторических наук К.М. Байпакова

В период с 2001 по 2003 гг. 3.Ж. Шарденова была членом Между- народной археологической экспедиции ЮНЕСКО-Казахстан-Япония «Сохранение и консервация древнего городища Отрар», проводившей археолого-консервационные работы на Отраре и городищах Отрарского оазиса.

В 2005-2007 гг. обучалась в очной докторантуре НАН РК. Работала над докторской диссертацией «Средневековое архитектурное наследие Казахстана».

3.Ж. Шарденова изучала объекты архитектуры и градосторительства средневековых памятников Казахстана, работая на стыке археологии и архитектуры. Ею были исследованы, а затем изданы научные статьи по планировке бани-хамам городища Отрар, архитектуре цитадели городища Куйрыктобе и многих других археологических и архитектурных памятников Южного Казахстана и Жетысу, а также она принимала участие в археолого-консервационных работах на комплексе Акыртас в Таласской долине.

Светлая память о Зухре Жанатаевне сохранится в наших сердцах.

\section{Список основных публикаций 3.Ж. Шарденовой *}

\section{Автореферат:}

Раннесредневековая жилая архитектура Южного Казахстана и Семиречья (VI - начало IX в.): автореф. дисс. ... канд. архитектуры. Ташкент: Ташкентский архитектурно-строительный институт, 1995. 34 с.

\section{Участие в книгах:}

1. Раннесредневековая архитектура Семиречья и Южного Казахстана на Великом Шелковом пути. Алматы: «Гылым», 2001. 238 с. (в соавт. с Байпаковым К.М., Перегудовой С.Я.).

2. Городище Костобе // Свод памятников истории и культуры Республики Казахстан. Жамбылская область. Алматы: РГП «НИПИ ПМК», 2002. Т. 2.350 с., карты, ил. С. 101-104 (в соавт. с Байпаковым К.М.). 
3. Комплекс Акыртас // Свод памятников истории и культуры Республики Казахстан. Жамбылская область. Алматы: РГП «НИПИ ПМК», 2002. Т. 2.350 с., карты, ил. С. 145-150 (в соавт. с Байпаковым К.М.).

\section{Статьи:}

1. О перекрытии обходного коридора во дворце Костобе (Джамукат) // Известия НАН РК. Сер. обществ. наук. 1993. № 5 (191). С. 36-40.

2. Архитектура цитадели Куйрыктобе на Сырдарье // Археологические памятники на Великом Шелковом пути. Алматы: Институт археологии им. А.Х. Маргулана, 1993. С. 28-44 (в соавт. с Байпаковым К.М.).

3. The monuments of dwelling architecture in early Medieval towns of Kazakhstan // Известия НАН РК. Сер. обществ. наук. 1995. № 4 (203). С. 74-83.

4. Строительные материалы и конструкции в раннесредневековой архитектуре Южного Казахстана и Семиречья // Известия МН-АН РК. Сер. обществ. наук. 1996. № 2 (207). С. 75-81.

5. Об архитектурном памятнике Баба-Ате в Южном Казахстане // Ата-мұра: сб. статей, посвящ. 75-летию Южно-Казахстанского областного историко-краеведческого музея. Шымкент, 1995. С. 110-117 (в соавт. с Байпаковым К.М.).

6. Монументальная архитектура в раннесредневековых государствах (VIIIX вв.) // Эволюция государственности Казахстана: матер. междунар. конф. (Алматы, 3-5 апреля 1996 г.). Алматы, 1996. С. 54-58 (в соавт. с Байпаковым К.М.).

7. Храм огня в цитадели Баба-ата // Известия МН-АН РК. Сер. обществ. наук. 1998. № 1 (213). С. 67-72.

8. Замок правителя на городище Акыртас // Известия МОН РК, НАН РК. Сер. обществ. наук. 2000. № 1 (224). С. 186-196.

9. Архитектура и строительная техника средневекового Казахстана // Промышленность Казахстана. 2002. № 4. С. 96-97 (в соавт. с Байпаковым К.М.).

10. Дворец арабских зодчих в Казахстане // Известия НАН РК. Сер. обществ. наук. 2004. № 1 (242). С. 144-153.

11. Работы ЮККАЭ в 2002-2003 гг. // Известия НАН РК. Сер. обществ. наук. 2004. № 1 (242). С. 194-223 (в соавт. с Байпаковым К.М., Савельевой Т.В., Ержсиитовой А.А., Ахатовым Г.А., Лобасом Д.А., Шербаевым Р.К., Воякиным Д.А.).

\section{Сведения об авторе:}

Ержигитова Айсулу Аскаровна - заведующая отделом археологии, Туркестанский областной историко-краеведческий музей (г. Шымкент, Казахстан); aisulu6767@mail.ru

\section{З.Ж. ШАРДЕНОВАНЫ ЕСКЕ АЛУ}

\section{А.А. Ержігітова}

Естелікте 2019 жылғы наурыз айының басында өмірден озған 3.Ж. Шарденованың ғылыми шығармашылығының негізгі кезеңдері айтылады. Зухра Жанатайқызының еңбек жолы Ш. Уәлиханов атындағы Тарих, археология және этнография институты археология бөлімінен басталып, кейіннен Ә.Х. Марғұлан атындағы Археология институтының урбанизация және номадизм бөлімінде 
жалғасын тапты. З.Ж. Шарденованың ғылыми қызығушылығы, архитектор мамандығы болғандықтан болар, негізінен ортағасырлардағы қала мәдениеті ескерткіштерінің құрылымдық ерекшеліктерін зерттеу болды. Кандидаттық дисертациялық жұмысы да IV ғасырдың басынан IX ғасыр аралығындағы Оңтүстік Қазақстан мен Жетісудің тұрғын жай архитектурасын талдауға арналған. 3.Ж. Шарденова өмірінің соңғы жылдары Ақыртас қорғанының архитектуралық ерекшеліктерін зерттеумен айналысқан болатын.

Түйін сөздер: археология, З.Ж. Шарденова, архитектор, ортағасырлар архитектурасы

\section{TO THE MEMORY OF Z. SHARDENOVA}

\section{A.A. Erzhigitova}

The article describes the main milestones of scientific creativity of Z. Shardenova, who passed away at the beginning of March 2019. First, Zukhra's labor biography was mainly associated with activities in the department of archaeology at Ch.Ch. Valikhanov Institute of History, Archaeology and Ethnography, and then in the department of urbanization and nomadism at A.Kh. Margulan Archeology Institute The sphere of her scientific interests, an architect by specialty, assumed the study of the Middle Ages' urban culture sites design features. Her Candidate dissertation was dedicated to the analysis of residential architecture of South Kazakhstan and Jetysu from the beginning of the IV to the IX centuries. In the last years Z. Shardenova studied architectural features of the Akyrtas castle.

Keywords: archaeology, Z. Shardenova, architect, architecture of the Middle Ages

\section{About the Author:}

Erzhigitova Aisulu A. Head of the Department of Archaeology, South Kazakhstan Regional Museum of Local History, Shymkent, Kazakhstan; aisulu6767@mail.ru 